\title{
The Novel in Post-Colonial Literatures: Re-Mapping the Genre
}

Florence Labaune-Demeule

\section{(2) OpenEdition \\ 1 Journals}

Electronic version

URL: https://journals.openedition.org/ces/4914

DOI: $10.4000 /$ ces.4914

ISSN: 2534-6695

Publisher

SEPC (Société d'études des pays du Commonwealth)

\section{Printed version}

Date of publication: 1 April 2016

Number of pages: 109-121

ISSN: 2270-0633

\section{Electronic reference}

Florence Labaune-Demeule, "The Novel in Post-Colonial Literatures: Re-Mapping the Genre",

Commonwealth Essays and Studies [Online], 38.2 | 2016, Online since 06 April 2021, connection on 01

July 2021. URL: http://journals.openedition.org/ces/4914 ; DOI: https://doi.org/10.4000/ces.4914

\section{(2) $\Theta \Theta \Theta$}

Commonwealth Essays and Studies is licensed under a Licence Creative Commons Attribution - Pas d'Utilisation Commerciale - Pas de Modification 4.0 International. 


\section{The Novel in Post-Colonial Literatures: Re-Mapping the Genre}

This essay looks into some of the ways in which post-colonial writers have addressed the Euro-centric canon of the British novel. Although most of them became familiar with it in the course of their school education, they have often de-centered the canon in order to propose a new cartography of the genre, thus endowing it with new impetus. After highlighting the role of intertextuality and hybridisation in post-colonial texts, our attention will return to generic hybridity. This will lead us to wonder whether the post-colonial novel can itself be viewed as a new literary canon.

That the origins of the novel are to be found in Europe has now been accepted as self-evident. Marthe Robert's illuminating study in Origins of the Novel (1976), or Ian Watt's enlightening analysis in The Rise of the Novel (1957) are among the basic critical texts on the subject. If it is widely accepted that the English novelistic genre is rooted in the picaresque tradition and that it continually expanded throughout the eighteenth century, one cannot but acknowledge that its expansion also corresponds, in a way, to the development of British imperialistic longings, ${ }^{1}$ a fact which Edward Said explains at length in Orientalism. ${ }^{2}$ Although it was instrumental in passing on Victorian and imperialistic values, the novelistic genre has also clearly been a space devoted to expressing freedom. "As a yet ill-defined genre, likely to induce multiple changes ranging from the adventure novel to the romance, from the epistolary novel to the Bildungsroman, this flexible form can mostly be defined by the fact that it rejects any rule and constraint: it is a place of complete freedom for the novelist," writes Florence Bancaud-Maënen (Bancaud-Maënen 19-20, translation mine). ${ }^{3}$

Yet, although the genre was radically questioned and challenged after WWII, not only did it endure, but it also emerged as more powerful, and has come to enjoy a true revival in recent years. The contribution of post-colonial literatures played no small role in this ${ }^{4}$ as, for instance, illustrated by the stormy relationship that V.S. Naipaul maintained with the novelistic genre, at times decrying it before finally designing it anew, curbing the genre to his own purposes and claiming it as one of his favourite means of expression..$^{5}$

And yet, here lies a paradox: most post-colonial writers, nourished by the literary (and novelistic) British canon ${ }^{6}$ during their formative years in the British colonies (or

1. "Yet, the eighteenth century holds a crucial place in the history of the novel. This genre hallows the fact that ancient forms were abandoned - forms such as the heroic epic genre, the genres of the sermon, of the pastoral, of eulogy or of the exemplary story, and it marks the coming of age of prose writings" (Bancaud-Maënen 9, translation mine). See also Cervantes \& Dachez.

2. See Said in Orientalism. This has also been highlighted in Clavaron 3.

3. See also Cervantes \& Dachez 139-44: "Concerning this issue, if that period truly marks the emergence of the novel, $[\ldots]$ it would be a mistake to believe that novel-writers followed well-established rules. This genre in the making was in fact in the process of evolving and it was constantly seeking a new definition, a situation which gave the writers the opportunity to carry out different literary experiments." (Translation mine)

4. See Grieve \& Cachin 7 and 48.

5. See Labaune-Demeule, V.S. Naipaul 123-52.

6. Nirmala Menon, quoting from the Oxford English Dictionary, reminds us of the definition of what a literary canon is: "The Oxford English Dictionary (OED) defines the noun 'canon' as a body of literary works traditionally regarded 
former British colonies) often used the literary canon and the novel as a means of expressing their own contestation and even rebellion. ${ }^{7}$ To do this, they relied on several specific methods, which this paper proposes to examine with the aim of showing that by revisiting the novelistic genre post-colonial literatures have also de-centered the canon and have proposed a new cartography of the genre, re-mapping it and giving it a new impetus.

\section{Post-Colonial Literatures and the British Literary Canon: The Role of Intertextuality and Hybridisation}

As several critics have pointed out, most post-colonial writers (particularly those belonging to the first generation of writers) were educated in the British colonial education system, notably by religious mission schools. The British literary canon offered them spiritual and literary knowledge (depending on various local contexts), and led them to master a language which had often initially been viewed as the language of the colonizer - "the language of the Master" in K. Ramchand's words.

So, many of the first post-colonial texts aimed at denoucing the European canon by speaking out against "Western models which had been imported, and which they try to repudiate, to revise, or both at the same time, in order to invent a new literay norm" (Claveron 71, translation mine). Among the most frequently used stylistic devices, irony, satire, or the grotesque have often been highlighted. This can, for instance, be illustrated in some of V.S. Naipaul's first short stories published in Miguel Street. In "His Chosen Calling," Naipaul introduces a character - Elias - who thinks that Cambridge is somebody's name ("Mr. Cambridge"). ${ }^{8}$ Naipaul also uses the same device by highlighting the cultural and social gap separating Britain and the Caribbean in A House for Mr Biswas, when Mohun Biswas wants to acquire some professional training in the field of journalism, or even later in Half A Life where Naipaul denounces, in a very satirical way, how literature was taught in colonial India, the great romantic poet Wordsworth being reduced to a mere meaningless initial - W.

Moreover, the British canon has often been challenged in post-colonial novels by a particular use of the English language, often peppered with dialects and local idiosyncrasies: many writers, like Sam Selvon, for instance, or Edwidge Danticat, who belongs to another generation of writers, have used dialect in their novels; others have relied on the use of more local sub-genres, like that of the calypso, as Naipaul did in Miguel Street. Other writers, such as Edward Kamau Brathwaite in "Nation language," have mixed up African rhythms and words in their texts not really to give them more local colour, but to convey the truth of experience. ${ }^{9}$ So the English language, enriched with contextual

as the most important, significant and worthy of study, those works esp. Western literature considered to the established as being of the highest quality and most enduring value. [...] The OED also records the changes in and expansion of the meaning of the word 'canon' brought about by intellectual debates, specifically those of feminist and postmodernist disciplines. Thus, a 1992 supplement to the definition of 'canon' is: 'A body of work considered to be established as the most important or significant in a particular field' (Oxford English Dictionary Online).” (Menon 218-31)

7. The title of Bill Ascroft, Gareth Griffiths, and Helen Tiffin's now very famous book, The Empire Writes Back bears testimony to that. See also Clavaron 69: "Post-colonial literatures, which are multicultural by essence, are part of an antagonistic framework addressing the European or Western canon, which they repudiate while appropriating it." (Translation mine)

8. See "His Chosen Calling" in Naipaul's Miguel Street 25-32.

9. "One may [...] think of Kamau Brathwaite's History of the Voice (1979) and his reminder that 'the hurricane does not roar in pentameter,' noting the iappropriateness of Western forms to Caribbean self-expression [...]” (Schabio 49). 
and local features, could resonate with the numerous sounds of diverse cultures. If that has been particularly true of poetry, the same thing can be said of post-colonial novels. While some of Walcott's poems, like "Sainte Lucie," in which lists of names resonate as prayer-like evocations and linguistic celebrations of Caribbean places, post-colonial novels also introduce local elements which contribute to asserting their own individual identity. For Walcott, as for many writers, these local names which are inlaid in texts like jewels do not only aim at documenting some form of local existence. They also testify to the writers' desire to claim, through the synchronic use of the language, the past diachronic use of a language which has helped the new generations to create, or recreate, the opacity of a negated cultural past. The language thus appropriated regenerates and sows new, hybrid seeds in a mixed and shared cultural land(scape) again, which imperialism had eroded and erased through colonisation. For some writers, choosing certain local words helps them root their discourse in the local culture. The discrepancy between the meanings of a word used by a particular character then becomes highly significant. For instance, when Antoinette Cosway, in Jean Rhys's novel Wide Sargasso Sea, calls the summer house "the ajoupa," (52) she refers to what she deems to be the exact reality of the islands. Her choice of the local idiom highlights the fact that Antoinette cannot be dissociated from her local background. On the contrary, when her English husband keeps using the English expression, ${ }^{10}$ he emphasizes his Englishman's (or foreigner's) vision of the place, insisting on their already divergent points of view. This technique is also very frequently used in anglophone Indian novels, for instance, which propose a glossary of Indian words to help the readers find their way through the maze of often unknown local terms.

However, the British literary canon in general, and the British novel in particular, have also often served as a bedrock for post-colonial literatures to build on in the form of palimpsests. ${ }^{11}$ The most significant illustration of this can also be found in Jean Rhys's Wide Sargasso Sea, where the revision of the madwoman's portrait drawn in Charlotte Brontë's Jane Eyre is analysed in a new light. Rhys's novel truly invalidates the simplistic, stereotypical and prejudiced Victorian vision according to which White Caribbean women were lunatics. In Rhys's novel, the revision becomes particularly meaningful because of the innovative introduction of multiple narrative voices which blur identification and contrast with Jane's narrative. Revision does not only consist in portraying the main character in a new light, nor does it only rely on the introduction of a subversive temporal pattern, Rhys's posterior novel being actually written as a prequel to Brontë's. Revision is expressed through a much subtler narrative pattern and the use of stylistic devices which recall Brontë's style, but for a different purpose - to invalidate Brontë's Victorian vision while paying homage to her style. ${ }^{12}$

Similarly, a more recent novel by David Dabydeen, A Harlot's Progress (1999) revisits Daniel Defoe's Moll Flanders while building upon the eponymous series of engravings by William Hogarth. Again perception has been displaced - and even doubly so - as narration is placed in the hands of Mr. Pringle who writes down old Mungo's confessions,

10. "Every evening we saw the sun go down from the thatched shelter she called the ajoupa, I [sic] the summer house." A footnote in the Norton Edition of Wide Sargasso Sea tells us that ajoupa is "a Carib word referring to an Amerindian-type hut with wattle-and-daub walls and a thatched roof." (Footnote 6, Rhys 52)

11. See Genette's Palimpsestes.

12. See for instance Delourme 262. 
while the latter also expresses his own point of view directly to the reader. The reader thus follows Mungo's story as well as Moll's. The character's age and his trials and tribulations echo Moll Flanders's, but they also introduce a new point of view - that of the young boy servant to be seen in the engravings of Hogarth who has now become an old man. Vision has then been displaced, "de-centered" if compared to the one introduced in both the literary and visual eighteenth-century works of art mentioned.

In a different although very efficient way, Derek Walcott's production also feeds on the novelistic literary canon. Although Walcott priviledges poetry as a form of expression, he also uses the literary canon as the bedrock of creation, for instance when he models his castaway character on Defoe's hero Robinson Crusoe. For Walcott, intertextuality takes the form of rewriting from similar material in a different genre. For him then intertextuality becomes another sign of cultural métissage which is almost as deeply ingrained in him and as vital to him as the mixed blood flowing in his veins. ${ }^{13}$

Such generic and literary métissage, or hybridity, explains why the character of Robinson Crusoe and that of the new American Adam - which are further illustrations of the author's multiple cultural allegiances - can be combined. In Walcott's poetry, Crusoe, the main character in what Walcott deems to be the first Caribbean novel, can be associated with the image of the man moulded out of clay, the first Adam the poet represents in his own New World of Caribbean creation.

So this leads us to observe that the way in which the British cultural or literary canon has been used over time in post-colonial literatures has changed greatly and that the British canon has not only been questioned by post-colonial writers, but that it has been used as some form of substrate from which post-colonial differences could be voiced, mostly through a process of hybridisation: it has generated literary hybridisation, which has also fostered a new hybridity of genres.

\section{Post-colonial Texts, or the Hybridity of Genres}

The hybridisation process of the novelistic genre within the context of post-colonial literatures relies on several factors and varies in nature and intensity. As suggested above, many stylistic devices or literary genres can be mixed or fused within the novelistic genre. Post-colonial novels are indeed characterized by their hybridity and the use of devices like magic realism, ${ }^{14}$ which is probably one of the hallmarks of post-colonial hybridity. Indeed, although "the word 'hybridity' has its origins in biology and botany," in the twentieth century it "extended beyond the biological and racial framework to embrace linguistic and cultural areas" (Guignery 2). Still later, in response to Homi Bhabha's influential thought, "postcolonial theory adopted the idea of hybridity to designate the transcultural forms that resulted from linguistic, political or ethnic intermixing, and to challenge the existing hierarchies, polarities, binarisms and symmetries [...]. Hybridity stands in opposition to the myth of purity and racial and cultural authenticity, of fixed

13. One can recall his famous poem entitled "A Far Cry from Africa," in which he expresses his despair at having to choose between the two cultures which he is part of (see Walcott 18).

14. "The magical realism of the Latin Americans influences Indian-language writers in India today. The rich, folktale quality of a novel like Sandro of Chegem, by the Muslim Russian Fazil Iskander, finds its parallels in the work - for instance - of the Nigerian, Amos Tutuola, or even Cervantes. It is possible, I think, to begin to theorize common factors between writers from these societies - poor countries, or deprived minorities in powerful countries - and to say that much of what is new in world literature comes from this group." (Rushdie, Imaginary Homelands 68-9) On hybridity, see also Brah \& Coombes, Kraidy, or Prabhu. 
and essentialist identity, embraces blending, combining, syncretism and encourages the composite, the impure, the heterogeneous and the eclectic" (Guignery 3). This is illustrated by Rushdie's narratives, which frequently mix tales typical of Eastern cultures with other genres, including the novel, in what often results in very jubilant composition. The mixing of highly elaborate literary passages with more oral ones, or with the fantastic or magic is characteristic of Rushdie's writing. Indeed, for Rushdie hybridity is the mirror of the disjunctions and fractures produced by displacement and uprootedness. Hybridity also offers a conjoint expression of different cultural points of view anchored in different traditions that the post-colonial writer's stereotypical vision can express (Rushdie, Imaginary Homelands 19). Thus, in Midnight's Children, Saleem Sinai is described as the embodiment of a multitude of people from different generations, displaying a multitude of experiences. Being the narrator of the novel, he becomes their unique but universal voice:

And there are so many stories to tell, too many, such an excess of intertwined lives events miracles places rumours, so dense a commingling of the improbable and the mundane! I have been a swallower of lives; and to know me, just the one of me, you'll have to swallow that lot as well. Consumed multitudes are jostling and shoving inside me [...]. (Rushdie, Midnight's Cbildren 9)

Midnight's Children, which stands half-way between the genre of the Eastern tale based on the Eastern oral tradition on the one hand, and the Western novelistic literary tradition on the other hand, relies on magic realism and hybridity as elements which make stylistic devices melt and fuse in a literary crucible thanks to imagination and fantasy (Grant 33). For Rushdie, if "Indian tradition has always been, and still is, a mixed tradition, [...] the nature of Indian tradition has always been multiplicity and plurality and mingling" (Rushdie qtd. in Goonetilleke 45). At the same time, he has also said that he wasreatly influenced by many European writers. ${ }^{15}$ This therefore translates in his books through the mingling of forms and genres.

Yet the hybridisation of genres can follow different paths in other circumstances. Thus, in her novel Mistress, Anita Nair relies on the traditional devices of the Western realistic novel when dealing with the ordinary life of the Shyam/Radha couple threatened by adultery, or when Radha's uncle Koman intervenes in their life. But onto this rather trivial plot of a love triangle, Nair superimposes a double narrative technique typical of the Indian and Keralese artistic traditions: the genres of the tale of origins and of the Indian epic act as basic elements in all the sections devoted to Koman's quest for origins, since he is a remarkable kathakali performer. Then, narrative hybridity is created by the intertwined use of both genres and their stylistic devices. The narrative is also constructed around the traditional architecture of kathakali performances, around the navarasas, the nine basic emotions expressed in kathakali. Each one is described in a different chapter, each chapter following the traditional order in which these emotions are performed on stage in kathakali dances. Each chapter also obeys the traditional

15. "He continued to tap the same rich vein and became aware of his true position as a writer. In one way, he allied himself to the non-realist, alternative tradition in Western fiction - Cervantes, Rabelais, Sterne, Swift, Melville, Gogol, Joyce, Günter Grass, Borges, Garcia Maquez. He said: 'In almost every country and in almost every literature there has been, every so often, an outburst of this large-scale fantasized, satiric, anti-epic tradition, whether it was Rabelais or Gogol or Boccacio... That simply was the literature I liked to read. So it seemed to me that it was also the literature that I would like to write."' (Goonetilleke 17) 
structure to be found in kathakali, with sloka and padams. ${ }^{16}$ Hybridisation is not only thematic, but also profoundly structural.

Hybridisation can also be found in the form of the mixing of different narrative genres within the frame of the novel. Thus, Fred D'Aguiar's novel The Longest Memory does not obey one unique narrative and generic design although narrative unity is achieved through the use of first-person narration throughout. This apparent unity conceals a multitude of narrative $I$-s expressing themselves in different chapters, thus enabling these $I$-s to voice their own form of subjectivity. Therefore this technique generates a strong impression of polyphony, the characters' spoken discourses being mixed with their thoughts, and each first-person narrative voice quickly following another one (even conflating into the other one). This polyphony is strengthened by the use of various literary genres in different chapters: poetry expresses Chapel's point of view since he is a young utopian poet, while newspaper editorials from The Virginian act like testimonies from the past, transmitting the values of the slave society. Diary entries also convey the racist values of the former manager (Sanders Senior) through his writing. Although these devices showcase the subjectivity of the characters, they also highlight the disruptions between the characters' values, just as they finally allow the reader to constantly re-evaluate slavery and its context. The resurgence of different genres and voices perceptible through the hybridisation of narration is an efficient means of opposing the cultural erasure that hegemonic cultures imposed on allegedly weaker cultures. Here again we find one of the major aims of post-colonial literatures - denouncing past horrors and condemnable values and attitudes.

In other post-colonial novels, the hybridisation of genres can also be linked to the use of autofiction and the introduction of particular relationships between the text and images - either photographs or paintings. Visual arts and genres can therefore affect the novelistic genre and lead to more generic hybridity. Thus, in The Enigma of Arrival, V.S. Naipaul explains that he found inspiration to write the novel from seeing reproductions of paintings by De Chirico in a small book. What is essential to him is to show how the main character's relationships to the pictures evolve and how his various narrative drafts are gradually expanded upon and transformed into the final novel which, at first sight, has little in common with De Chirico's paintings. De Chirico's "Enigma of Arrival" is a source of inspiration in terms of plot but also because it introduces a new metaphysical perception and requires a constant repositioning of the viewer, a technique that Naipaul reproduces for the reader, who has to understand the performative and anamorphotic value of the narrative (cf. Labaune-Demeule, V.S. Naipaul).

Though it is couched in different terms, Jamaica Kincaid's novel The Autobiography of My Mother comes close to that experience. Here, the hybridisation process is less perceptible and is more double-sided. First, the genre of the autobiography fuses with that of the novel, which is not surprising in itself since post-colonial writers often priviledge this genre as a way of exploring the primeval self. ${ }^{17}$ In her quest for origins and self-knowledge, the young Caribbean girl named Xuela tells us of her life, which

16. In addition to P. Zarilli's seminal analysis, see Labaune-Demeule "Anita Nair's Aesthetics of Hybridity: Mistress as Narrative Kathakali."

17. "Autobiography is a form that allows the individual to tease out his or her genealogical complexity and as a result to better understand him or herself. Race and ethnicity are always a point of focus in coming to terms with the notion of identity, and in this region where people's racial and ethnic makeup is typically multi-layered, they become especially crucial." (Pouchet-Paquet qtd. in Adams 11) 
seems to run parallel to her mother's own life - a mother whose name had been given to the young girl, and who had died in childbirth. By weaving together young Xuela's first-person narrative of her own life, and what she can learn about her mother's life as well as the life of other people living close to her, young Xuela manages to create herself, to get some form of personal identity, while she recreates her own past and learns about her mother's life. Such a purpose can be achieved only through the genre of the autobiography, a genre which proved essential to J. Kincaid herself: ${ }^{18}$

$[T]$ here is no reason for me to be a writer without autobiography [...] For me [writing] was really an act of saving my life, so it had to be autobiographical. I am someone who had to make sense out of my past. (Kincaid qtd. in Ferguson 10)

However, autobiography does not encourage distancing, unlike the novel which facilitates the objectification of the self and, beyond that, the objectification of reality itself. The somewhat hybrid genre of autofiction enables writers to stand half-way between subjectivity and objectivity while using auto- or homo-diegetic narration. Autofiction, as defined by Serge Doubrovsky, gives a writer the opportunity to get more distance from facts and self than autobiography. As Claude Burgelin also explains being able to place one's past and personal history at a distance enables one to reappropriate one's past (54). Both the time scheme of experience and the time scheme of discourse can be fused together. This is exactly what happens with Jamaica Kincaid's novel, as is explicitly metaphorised by the photograph that can be observed on the book cover. The photograph, which is totally fragmented at the beginning of the narrative, is gradually re-composed as Xuela's identity quest reaches its final aim. The portrait of the unknown mother can be gradually reconstituted as young Xuela's quest progresses to more selfknowledge. The mother's recomposed portrait finally proposes to the reader a portrait of Xuela herself. At the end of the narrative, all the pieces in the jigsaw puzzle of the photograph have fallen into place, and Xuela realizes that she has finally found the meaning of her life:

This account of my life has been an account of my mother's life as much as it has been an account of mine, and even so, again, it is an account of the life of the children I did not have, as it is their account of me. (Kincaid 227)

Autofiction, therefore, helps writers to blur the limits between the $I$-narrator and the multiple - though partial - representations of the $I$-character that the narrative reflects back to her/him. Autofiction becomes the place where hydridisation occurs, affecting a genre and a voice. This, in fact, echoes what C. Burgelin means when he calls autofiction a "bastardized genre, which relies on mixing and compromise" (5). ${ }^{19}$ The paradox to be found in Jamaica Kincaid's title, The Autobiography of My Mother, then becomes transparent to the reader: the autobiography of Xuela, which is an autodiegetic narrative, is also her mother's autobiography, just as it is the autobiographies of all those Xuelas who shared the same fate as hers. The autobiography, which is a genre in which narrated and narrating $I-\mathrm{s}^{20}$ fuse, gradually becomes an autofiction, that hybrid genre that was genera-

18. Pouchet-Paquet qtd. in Adams 11.

19. C. Burgelin adds that the notion of autofiction, though ill-defined, can be extended to suit different aims, that the frontiers it shares with the autobiographical novel are blurred, and that autofiction is, today, submitted to a similar bastardisation process as that which had characterised the novel in the past, being also based on a similar process of métissage (6-8).

20. This is used to refer to Gérard Genette's twofold concept of the narrated I and the narrating I. 
ted by the métissage of the novelistic and autobiographical genres. The photograph is the representation of a both unique and multiple-faced woman, in a form of virtual reality described in the autofiction. $I$ is also a double-sided she (both mother and daughter), and a they, representing all these women with similar fates.

So, faced with such deep changes within the canonical British novel, one can wonder whether post-colonial writers are not redefining the boundaries of the novel.

\section{Re-Mapping the Genre: The Post-Colonial Novel as a New Literary Canon? ${ }^{21}$}

Because it is a flexible and adaptable genre, the novel has undergone profound changes over time. It appears to be a privileged space of hybridisation. The first sign of displacement or dis-location of the canonical genre can be seen in the shifting of the genre from the metropolitan centres to the colonial and post-colonial margins. By taking hold of this typically metropolitan genre, post-colonial writers have de-centered it, rejecting the Eurocentrism that characterized it at first in order to transform it from within, by giving the genre some of their own characteristics by intertwining and mixing local devices and specificities in its original patterns. If the first post-colonial novels often strongly contested a Eurocentric and colonialist vision of the world, post-colonial writers have later insisted on the need to make the genre more dynamic again as it had become a deeply contested form even in Europe after WWII. It has now become the means to convey more, sometimes hard-won, freedom, as Pascale Casanova writes in La République des Lettres. 22 The term arrachement (uprooting) used by Casanova obviously recalls the concept of root-like identity developed by Deleuze and Guattari as well as by E. Glissant in the Caribbean. ${ }^{23}$ However, the malleable nature of the novelistic form also evokes the more significant image of the rhizome, thus describing how post-colonial literatures are transforming the novelistic genre by following a horizontal pattern this time. The rhizome can indeed be viewed as the physical expression of a desire to de-territorialize, as opposed to the root concept, evoking a plant that is firmly set in the ground. In an analogous way, post-colonial literatures strive to de-territorialize the novel to "de-Europeanise" it, as it were, by giving it multiple features. And the rhizome is also the a place, and as such, post-colonial literature truly wants its expression of a desire to re-territorialize subject to re-territorialize the novelistic genre:

In a book as in all things, there are lines of articulation or segmentarity, strata and territories; but also lines of flight, movements of deterritorialisation and destratification. [...] A first type of book is the root-book. [...] This is the classical book, as noble, signifying and subjective organic interiority (the strata of the book). [...] A rhizome

21. This has recently emerged as a major preoccupation: "In the field of post-colonial studies questions of subversion, parody, and mimesis have predominated over other aspects of aesthetic form. It is high time to attempt to explore wider dimensions of a postcolonial aesthetics, a main aspect of which being specificities of genric evolution or emergence." (Goebel \& Schabio 1)

22. "Post-colonial literature will gradually invent itself, while slowly uprooting itself from its 'political duty': first obliged to serve, through language, 'national' (that is, political or state-level) purposes, writers are gradually creating the conditions of their own literary freedom through the invention of specific literary languages." (Casanova 70, translation mine)

23. G. Deleuze and F. Guattari explain that one can conceive of books as pertaining to two major categories: that of the root-like book and that of the rhizome-like book. The former reflects the organic interiority of the classical book, whereas the latter illustrates a more modern conception of books (11-2). The two categories reflect a fundamental difference in systems of spatial representation between mere imitation, or mimesis which they compare to "decalcomania," and symbolic mapping (9-20). 
as subterranean stem is absolutely different from roots and radicles. [...] The rhizome itself assumes very diverse forms, from ramified surface extension in all directions to concretion into bulbs and tubers. (Deleuze \& Guattari 3-7)

Deleuze and Guattari add that a rhizome includes segmentarity lines which territorialize and organize it, but that it also includes deterritorialising lines through which it can expand or spread (16). The principles that constitute a rhizome - the principle of connection and heterogeneity, the principle of multiplicity, the principle of a-signifying rupture, among others - are truly representative of what can be observed in the evolution of the post-colonial novel as a sub-genre. Yet Deleuze and Guattari have also developed another crucial concept - that of cartography, or mapping, which they associate with the rhizome image, since they consider that the principle of cartography also characterises the rhizome, and that as such the concept radically differs from mimesis, which they liken to a decalcomania. For Deleuze and Guattari, a map is a way of spatially materialising the rhizome; it helps connect different fields together, opens itself to the world, and can adapt to many different situations (20). G. Huggan also establishes a link between mapping and postcolonial literatures, and further explains:

The map no longer features as a visual paradigm for the ontological anxiety arising from frustrated attempts to define a national culture, but rather as a locus of productive dissimilarity where the provisional connections of cartography suggest an ongoing perceptual transformation which in turn stresses the transitional nature of postcolonial discourse. This transformation has been placed within the context of a shift from an earlier "colonial space" to a later, "post-colonial" fiction which emphasizes the provisionality of all cultures and which celebrates the particular diversity of formerly colonized cultures [...]. Thus [...] the reassessment of cartography in many of their most recent literary texts indicates a shift of emphasis away from the desire for homogeneity towards an acceptance of diversity reflected in the interpretation of the map, not as a means of spatial containment or systematic organization, but as a medium of spatial perception which allows for the reformulation of links both within and between cultures. (356)

Consequently, the post-colonial novel, as a sub-genre, appears very much today like a map which spreads and grows, tracing moving paths to appropriate new territories. V.S. Naipaul's novel The Enigma of Arrival (1987) purposefully sets for itself the aim of drawing such a cartography or literary map - a vivid and shifting cartography of the almost elusive psychological state of the autodiegetic narrator-writer who stages himself as writing an autofiction which is nevertheless explicitly introduced by the author as a novel. ${ }^{24}$ This narrative can be viewed as a real and performative exercise in geographical and psychological cartography. Geographical mapping first, because the reader follows directly in the steps of the character who explores his new Wiltshire landscape, remembering the slightest topographical references of the character's own ramblings in the Wiltshire downs, following in detail all of the protagonist's mistakes and hesitations, his misunderstanding of certain scenes as well as his erroneous interpretations of the landscape or the revelations of which he becomes aware, the reader finally reaching the same understanding of the landscape as the character-narrator.

24. Naipaul's novel is subtitled "A novel in five sections." W. Goebel points out the uncertain generic nature of The Enigma of Arrival which he views as a form of heterobiography: "The Enigma of Arrival is perhaps Naipaul's most complex autobiographical text. [...] Naipaul's entire world seems to open up into an egocentric kaleidoscope of lost possibilities and fractured existences, which could be called a heterobiography. The term alludes to the heterogeneity of texts and genres in his autobiographical fictions [...]." $(113,115)$ 
This long process leads to a new cartography of the place, to the drawing of a verbal map which comes to replace, probably in more efficient a way, what a traditional map would have offered. The narrative covers the periods of initiation and of appropriation of the new place. This process also involves the reader because, thanks to the performative aspect of the narrative, reader and narrator are always looking for new paths together following the narrative map of the novel. Like a rhizome, The Enigma of Arrival is a performative novel, a novel on the move, with offshoots reaching out for new horizons, new meanings.

The rhizome and the map also allow for a new form of communication which conflicts with what the previous canonical systems had established. While canonical novels openly introduced the presence and authority of the narrator's persona (whether auto-, homo-, or hetero-diegetic), the post-colonial novel tends to do away with classical narrative positions, for instance by imposing silence as a means of communication between the instances at play in a novel - from implied author to reader. This, therefore, entails the displacement of canonical norms, the displacement of discourse, since discourse is the very essence of the novel. By conferring a privileged position on silence, an implied author can displace one of the most characteristic devices of the canonical novel, both as a theme and as a radical means of questioning discourse.

This is how Edwidge Danticat establishes a form of invisible cohesion between several, apparently disconnected short stories in her novel The Dew-Breaker. The short stories should not be conceived of as separate entities. It is their silent juxtaposition that gives meaning to the whole narrative. Speaking of "a poetics of fragmentation," Mary Callagher notes:

The Dew Breaker spans nine chapters, each shaped as an individual story, most of which were published as separate short stories and subsequently rewritten slightly for inclusion in the book. [...] The structure raises many questions, but rather than asking how successful the book is as a novel; and to what extent it remains a collection of stand-alone units that create a sense more of dicontinuity than of consequential development of character or plot, readers find themselves searching for secret passages connecting the eponymous plot and the individual stories, even if the author might not seem to have provided enough keys to identfy the links. This hermeneutic shortfall opens up the meaning of the individual stories, the suspicion of a hidden continuity lending each story additional, if uncertain, depth. Moreover, the fragmentation of the book's structure itself enacts the brokenness of the lives portrayed and performs the concealment, displacement, and disconnection that the book also configures thematically. (148)

Mary Gallagher also analyses Danticat's writing in terms of the poetics of fragmentation and of resonance that is being created in the silent dialogue established between the short stories (Gallagher 157). We could even speak here of a poetics of silence, through which Danticat really suggests a particular interpretation, or a deciphering of the rhizome or, to take up Mary Gallagher's own terms, a poetics according to which "[the novel] incites and rewards a reading open to the multiple, layered, if not concealed, relations that it establishes on the levels of genre, language, narrative, text, theme, and plot" (Gallagher 160).

Contrasting roots with itineraries, or routes is another way of addressing the root vs. rhizome dichotomy, since the word route opens new, dynamic perspectives, as many critics have argued, from Edward Kamau Brathwaite to Edouard Glissant, and from Paul Gilroy to James Clifford. If post-colonial theory as a whole has famously engaged with 
issues of globalisation, diaspora or the concept of transnation, it has also paid considerable attention to the current status of the post-colonial text. ${ }^{25}$

Some question the paradoxical situation of post-colonial literatures, the initial aim of which was to repudiate, or problematize, the Western literary canon. Today, postcolonial literatures seem to be ready to integrate the canon, to make it evolve and to leave it in the hands of Western publishers whose influence over their books seems crucial. ${ }^{26}$ Therefore, some post-colonial critics are skeptical about the evolution of the post-colonial novel. Others, like Nirmala Menon, question the very nature of what can be considered as the current post-colonial canon (Menon 218-31). This supposes a displacement of the very notion of the canon, insofar as post-colonial literature itself - although its initial aim was to undermine inherited norms - has now, in its turn, become canonized. ${ }^{27}$ According to Nirmala Menon, the only way of restoring vigour and direction to this new post-colonial canon would be to rely on its linguistic impetus, and take into consideration not only those novels written in English, but also the novels written in vernacular languages since "post-colonial spaces are vast and multilingual, and no single language - whether English or French - can by itself be representative of the diversity of experiences and literay forms that emerge from these places" (Menon 224). The critic also perceives in the systematic selection of books written in English, some traces of a form of imperialism which contradict the traditional position of postcolonialism, and which could finally be viewed as the creation of a post-colonial hypercanon. ${ }^{28}$ For Menon, being able to introduce readers to different literatures written in languages other than English would expose them to other forms and models, even if this requires translating these works into English. ${ }^{29}$ But what Nirmala Menon really highlights is the rhizomatic expansion of the canon when stating that " $\mathrm{t}]$ he canon should expand outwardly, not converge inwardly" (Menon 229). So, it is by including new forms, by relying on cultural and linguistic borrowings from various cultures whether they generate some form of hybridisation or not - by respecting diversity, that the post-colonial novel will impose itself in the face of a European canon which no longer represents the diversity of our times. ${ }^{30}$ Is the European canon going to be

25. See for instance sections 1 and 2 in Wilson et al. The essays authored by Bill Ashcroft ("Transnation"), Simon Gikandi ("Between Roots and Routes: Cosmopolitanism and the Claims of Locality"), and Patrick Williams ("Outlines of a Better World") are of utmost interest.

26. Yves Clavaron developed this point in respect to post-colonial francophone literatures (80).

27. "Whether we agree on the existence or irrelevance of canons, whether 'post-colonial canon' is a self-contradictory term or not, the field as currently formulated is dominated by select writers and literay works to the exclusion of other writers, works and languages." (Menon 220)

28. "In post-colonial literature, acknowledging only writers writing in English as part of a post-colonial literary corpus smacks of an imperial influence, not a post-colonial stance. Damrosch also points to the existence of a shadow canon in post-colonial studies [...] By circumscribing its orbits to a few, select authors in a single language, post-colonial studies create what David Damrosch calls a 'hypercanon' within that field." (Menon 225)

29. "Reading diverse narratives from different languages will also open up the discourse on theoretical concepts. There will be narratives that address issues that have not yet been confronted in existing theoretical models, or which can be articulated differently. Reading conflicting narratives will render these models more complex and tease out some of the difficult issues when dealing with representations of different cultures." (Menon 228)

30. This paper has only just skimmed the surface of the issue, and a longer essay would be necessary to develop many aspects. Just to show how complex this is, it can be said that the evolution of the post-colonial novel has to be gauged against "two main patterns for generic evolution/devolution: the earlier formalist one and Bakhtin's, that is a more devolutionary one and an evolutionary popular one. According to the first, new genres are born more or less spontaneously by the craft of the gifted author/artist who can assemble intertexts and remould them effectively, which then in the course of productive reception become automatized and popularized [...]. Bakhtin, on the other hand, highlights the formation process and emphasizes the influence of popular and communal forms, e.g. of speech genres and orality in 
overtaken by the post-colonial hyper-canon of anglophone post-colonial novels, then? This would no doubt be an ironical twist, which the post-colonial novel would probably soon exploit ironically.

As a conclusion, we can say that the European canonical novel has long been, and sometimes still is, an important stepping stone for post-colonial novelistic creation since it is still used at times as a literary bedrock that allows intertextuality and palimpsests. However, the post-colonial novel has learnt to transform this Western canon, twisting and adapting it to its own needs and requirements and bending it in specific ways by blending it with more local devices, by relying on non-European characteristics (magic realism, the inclusion of linguistic specificities and a variety of languages, the hybridisation process of diverse genres and forms, etc.) in its own literary crucible.

Speaking of setting up a new cartography of the post-colonial novel, or of re-mapping it, does not mean scanning the genre to propose a new typology of sub-genres. This would amount to something close to what Deleuze and Guattari call decalcomania. On the contrary, the approach underlying today's post-colonial novel has become a new suject of interest. Being able to propose a cartography of the post-colonial novel enables us to conceive of the genre not as a fixed, outmoded and threatened category, but as a rhizome whose offshoots spread towards an ever-expanding space, a genre which gives the reader the possibility to open and decipher an ever-changing map, taking into account each reader's subjectivity in a continually moving, active, performative movement which grants them new perspectives on the contemporary world. Such perspectives are very different from those introduced by the European canon which, in the past, served as an almost unique model imposed from the center. The genre has now been de-centered to reflect and express the multiplicity of the world.

Florence LABAUne-Demeule University Jean Moulin - Lyon 3

\section{Works Cited}

ADAms, Michelene. "Jamaica Kincaid's The Autobiography of My Mother: Allegory and Self-Writing as Counter-Discourse." Anthurium: A Caribbean Studies Journal 4.1 (Spring 2006): 1-15.

Ashcroft, Bill, Gareth Griffiths, and Helen Tiffin. The Empire Writes Back. Theory and Practice in PostColonial Literatures. 1989. London; New York: Routledge, 1994.

Bancaud-MaËnen, Florence. Le roman de formation au XVIIIe siècle en Europe. Paris: Nathan, 1998.

Brah, Avtar, and Annie E. Coombes. Hybridity and its Discontents. Politics, Science, Culture. London: Routledge, 2000.

Burgetin, Claude, ed. Autofictions. Lyon: P.U. de Lyon, 2010.

Casanova, Pascale. La république mondiale des Lettres. Paris: PUF, 1999.

Cervantes, Xavier, and Hélène Dachez. Le XVIIIe siècle anglais. Toulouse: PU du Mirail, 2002.

Clavaron, Yves. Poétique du roman post-colonial. Saint-Etienne: Publications de l'U de Saint-Etienne, 2011.

D’Aguiar, Fred, The Longest Memory. 1994. London: Vintage, 1995.

Deleuze, Gilles, and Félix GuatTari. A Thousand Plateaus. Translator Brian Massumi. London; New York: Continuum, 2003. Trans. of Mille Plateaux. Paris: Minuit, 1988.

Delourme, Chantal. "La mémoire fécondée. Réflexions sur l'intertextualité: Jane Eyre, Wide Sargasso Sea." Etudes anglaises 42.3 (1989) 257-69.

general, on the evolution of the new. [...] It goes without saying that there are many modes of the productive reception of forms between these two prototypical models of generic evolution and devolution.” (Goebel \& Schabio 3) 
Ferguson, Moira. "A Lot of Memory: An Interview with Jamaica Kincaid." The Kenyon Review, 16.1 (1994): 163-88.

Gallagher, Mary. "Concealment, Displacement and Disconnection: Danticat's The Dew Breaker." Edwidge Danticat. A Reader's Guide. Ed. Martin Munro. Charlottesville; London: U of Virginia P, 2010. 147-60.

Genette, Gérard. Palimpsestes. La littérature au second degré. Paris: Seuil, 1982.

Goonetilleke, D. C. R. A. Modern Novelists. Salman Rushdie. London: Macmillan, 1998.

Guignery, Vanessa. "Hybridity, Why it Still Matters." Hybridity. Forms and Figures in Literature and the Visual Arts. Ed. Vanessa Guignery, Catherine Pesso-Miquel and François Specq. Newcastle-uponTyne: Cambridge Scholars Publishing, 2011.

Goebel, Walter, and Saskia Schaвio. "Introduction." Locating Postcolonial Narrative Genres. Ed. Walter Goebel and Saskia Schabio. New York; London: Routledge, 2013. 1-10.

Goebel, Walter. "V. S. Naipaul's Heterobiographical Fictions or Postcolonial Melancholia Reinterpreted." Goebel and Schabio 108-23.

Grant, Damian. Salman Rushdie romancier. Translator Madeleine Descargues. Villeneuve d'Asq: PU du Septentrion, 2014. Trans. of Salman Rushdie. Northcote House: British Council, 2012.

Grieve, Ann, and Marie-Françoise CaCHIN. Le roman britannique depuis 1945. Paris: Nathan, 1996.

Huggan, Graham. "Decolonizing the Map." The Post-Colonial Studies Reader. Ed. Bill Ashcroft, Gareth Griffiths and Helen Tiffin. 1995. London; New York: Routledge, 2011. 355-8.

KInCAID, Jamaica. The Autobiography of My Mother. 1996. New York; London: Plume Books/ Penguin, 1997.

KRAIDY, Marwan M. Hybridity or the Cultural Logic of Globalisation. Philadelphia: Temple UP, 2005.

Labaune-Demeule, Florence. V.S. Naipaul. L'énigme de l'arrivée. L'éducation d'un point de vue Lyon: Editions universitaires de Lyon III, 2007.

-. "Parfois, nous pouvons être étrangers à nous-mêmes'. V.S. Naipaul et le roman: L'altérité/ altération d'un genre. Les romans tardifs et la tradition.” Labaune-Demeule 123-52.

-. "Anita Nair's Aesthetics of Hybridity: Mistress as Narrative Kathakali." Guignery, Pesso-Miquel and Specq 223-36.

Menon, Nirmala. "Rerouting the Post-Colonial Canon through Linguistic Remapping. Why Remap?" Wilson, Sandru and Lawson Welsh 218-31.

Naipaul, V.S. A House for Mr Biswas. 1961. Hardmonsworth: Penguin, 1969.

—. The Enigma of Arrival. A Novel. London: Penguin, 1987.

-. Half a Life. Basingstoke; Oxford: Picador/Pan Macmillan, 2001.

—. Miguel Street and The Mystic Masseur. 1957. Basingstoke; Oxford: Picador, Pan Macmillan, 2002.

NaIr, Anita. Mistress. London: Black Amber, Arcadia, 2007.

Pouchet-Paquet, Sandra. Caribbean Autobiography: Cultural Identity and Self-Representation. Madison, U. of Wisconsin P, 2002.

PrabHu, Anjali. Hybridity. Limits, Transformations, Prospects. Albany: State U of New York P, 2007.

Ramchand, Kenneth. The West Indian Novel and its Background. 1970. London: Heinemann, 1983.

RHYs, Jean. Wide Sargasso Sea. 1966. New York; London: Norton, 1999.

RoBert, Marthes. Roman des origines, et origines du roman. Paris: Gallimard, 1976.

Rushdie, Salman. Imaginary Homelands, Essays and Criticism, 1981-1991. London: Granta Books, 1991.

—. Midnight's Children. 1981. London: Vintage, 1995.

SAID, Edward. Orientalism. 1978. London: Penguin Classics, 2003.

SCHABIO, Saskia. “ ‘...At the Edge of Writing and Speech...' Shifting Genre, Relocating the Aesthetic.” Goebel and Schabio 44-57.

Walcoтt, Derek. Collected Poems 1948-1984. 1986. London: Faber \& Faber, 1992.

Watt, Ian. The Rise of the Novel: Studies in Defoe, Richardson and Fielding. 1957. London: Pimlico, Random House, 2000.

Wilson, Janet, Cristina Sandru, and Sarah Lawson Welsh, eds. Rerouting the Post-Colonial. New Directions for the New Millenium. Oxon; New York: Routledge, 2010.

Zarilui, Phillip. Kathakali, Dance-Drama. Where Gods and Demons Come to Play. 2000. London: Routledge, 2002. 